\title{
Dietary adaptations of temperate primates: comparisons of Japanese and Barbary macaques.
}

\section{$\operatorname{AUTHOR}(S)$ :}

Hanya, Goro; Ménard, Nelly; Qarro, Mohamed; Ibn Tattou, Mohamed; Fuse, Mieko; Vallet, Dominique; Yamada, Aya; ... Tsujino, Riyou; Agetsuma, Naoki; Wada, Kazuo

\section{CITATION:}

Hanya, Goro ... [et al]. Dietary adaptations of temperate primates: comparisons of Japanese and Barbary macaques.. Primates; journal of primatology 2011, 52(2): 187-198

\section{ISSUE DATE:}

2011-04

URL:

http://hdl.handle.net/2433/139581

\section{RIGHT:}

The final publication is available at www.springerlink.com; この論文は 著者最終稿です。内容が印刷版と異なることがありますので、引用の 際には出版社版をご確認ご利用ください。This is the Accepted Author Manuscript. Please cite only the published version. 
1 Dietary adaptations of temperate primates: comparisons of Japanese and Barbary

2 macaques

3

4 Goro Hanya, Nelly Ménard, Mohamed Qarro, Mohamed Ibn Tattou, Mieko Fuse,

5 Dominique Vallet, Aya Yamada, Moe Go, Hino Takafumi, Riyou Tsujino, Naoki

6 Agetsuma and Kazuo Wada

7

8 G. Hanya, A. Yamada, M. Go, K. Wada: Primate Research Institute, Kyoto University,

9 Inuyama, Japan

10 N. Ménard, D. Vallet: Station Biologique, CNRS-université Rennes, Paimpont, France

11 M. Qarro: Ecole Nationale Forestière d'Ingénieurs, Salé, Morocco

12 M. Ibn Tattou: Institut Scientifique, Université Mohammed V-Agdal, Rabat, Morocco

13 M. Fuse: Sasayama Field Station, Kobe University, Sasayama, Japan

14 H. Takafumi and N. Agetsuma: Field Science Center for Northern Biosphere, Hokkaido

15 University

16 R. Tsujino: Research Institute for Humanity and Nature

17

18 Correspondence to: G. Hanya: Primate Research Institute, Kyoto University, Kanrin

19 41-2, Inuyama, Aichi, 484-8506 Japan. E-mail: hanya@ pri.kyoto-u.ac.jp, Tel:

$20+81-568-63-0542$, Fax: +81-568-63-0564

22 Short title: Diet of temperate macaques 


\section{Abstract}

25 Habitat, diet and leaf chemistry are compared between Japanese and Barbary macaques

26 in order to reveal the similarities and differences in dietary adaptations of temperate

27 primates living at the eastern and western extremes of the genus Macaca. Tree species

28 diversity and proportion of fleshy-fruited species are much higher in Japan than in

29 North Africa. Both species spend considerable annual feeding time on leaves. Japanese

30 macaques prefer fruits and seeds over leaves and Barbary macaques prefer seeds. These

31 characteristics are adaptive in temperate regions where fruit availability varies

32 considerably with season, since animals can survive during the lean period by relying

33 on leaf and other vegetative foods. The two species are different with respect to the

34 higher consumption of herbs by Barbary macaques, and the leaves consumed contain

35 high condensed and hydrolysable tannin for Barbary but not for Japanese macaques.

36 Barbary macaques supplement less diverse tree foods with herbs. Because of the low

37 species diversity and high tannin content of the dominant tree species, Barbary

38 macaques may have developed the capacity to cope with tannin. This supports the idea

39 that the digestion of leaves is indispensable to survive in temperate regions where fruit

40 and seed foods are not available for a prolonged period during each year.

41 KEY WORDS: Barbary macaque, condensed tannin, Japanese macaque, leaf chemistry,

42 temperate forest

44 Introduction

45 Primates originated in the tropical rain forests (Fleagle 1999), but they have radiated

46 into various marginal habitats, such as woodlands, savanna and high mountains.

47 Temperate forest is one of those marginal habitats harboring approximately 20 genera 
within 8 families (Lemuridae, Indriidae, Cheirogaleidae, Lorisidae, Cebidae,

temperate and tropical regions as the tropics of Cancer and Capricorn (Fleagle 1999).

Among them, five species (Japanese and Barbary macaques, Sichuan and Guizhou golden monkeys, and golden langurs) are distributed exclusively in the temperate regions (Fleagle 1999). Although temperate primates are a minority within the order, it is expected that adaptations to temperate habitat have evolved in various lineages. day length. In addition, fruiting phenology in temperate forest is more seasonal than in tropical forest (Ting et al. 2008), and the fruiting peak tends to occur in a more limited time of the year (autumn). Consequently, fruiting phenology tends to be more seasonal and predictable in temperate forest than in tropical forest (Ting et al. 2008). In the former, fruit is commonly absent for several months of the year (Herrera 1984; Hanya et al. 2004). In some tropical forests, plant reproductive phenology is aseasonal or weakly seasonal (Sakai 2002). In most tropical forests, however, fruiting peaks are predictable,

63 but not all species peak in the same month (van Schaik et al. 1993; Ting et al. 2008).

64 Based on a review of 51 temperate and tropical forests all over the world, fruit fall in the tropical forests is, on average, 1.71 times larger than that in temperate forests (Hanya and Aiba, in press). The proportion of fleshy-fruited species, potential foods for

67 primates, is also smaller in temperate than in tropical forests (Willson et al. 1989). Therefore, fruit food availability (biomass of edible parts of fruits) seems to be smaller 69 in temperate than in tropical forests. 
72 (van Schaik et al. 1993), but the period of leaf flushing is confined to spring and early

73 summer in temperate regions (Agetsuma 1995; Komiyama et al. 2001). Therefore,

74 protein-rich young leaves cannot be used as a fallback food when fruits are not available,

75 particularly in winter.

76 Hanya (2004) revealed that Japanese macaques have two dietary

77 characteristics that are adaptive in temperate forests: 1) They eat substantial amounts of

78 leaves and other vegetative parts, while fruits and seeds are only minor foods; 2) Even

79 in the fruit-poor environments, they prefer fruits and seeds and eat them whenever they

80 are available. To survive in a fruit-poor environment, monkeys must adapt by eating a

81 large amount of leaf foods. In fact, the proportion of fruit-feeding time of temperate

82 macaques (Macaca fuscata, M. cyclopis, and M. mulatta: 9-54\%) is lower than that of

83 tropical macaques (M. fascicularis, $M$. radiata, $M$. nigra, and $M$. nemestrina: $59-70 \%$ )

84 (Hanya 2004). At the same time, preference for fruit is also useful in temperate regions

85 because food ingested in excess of daily requirements can be saved as fat to help

86 animals survive in the fruit-poor winter (Wada 1975). Since the fruiting phenology and

87 climate are highly annually periodic in temperate forests, it is possible for animals to

88 predict when to start fat deposition and how long a food shortage will last. In fact,

89 patterns of seasonal change in deposited fat are quite similar among different

90 populations of Japanese macaques, having peaks in early spring and late autumn,

91 corresponding to the seasonal change in food availability (Muroyama et al. 2006).

92 Therefore, dependence on deposited fat is a safe strategy in temperate regions, and fat

93 deposition is in fact prevalent in temperate and arctic endotherms (Pond 1978).

94 This paper compares habitat, diet and leaf food selection by two species of

95 temperate macaques, Japanese and Barbary macaques. We chose these species because 
96 1) they are among the most-studied temperate macaques and 2) they are the most

97 distantly located, at the eastern- and western-most extremes of the distribution of genus

98 Macaca. Japanese macaques are distributed widely throughout the Japanese archipelago

$99\left(\underline{30-41^{\circ} \mathrm{N}}\right)$. Their habitat includes both warm-temperate broad-leaved evergreen

100 forest and cool-temperate broad-leaved deciduous forest. They also live in coniferous

101 forests in high mountains (Izumiyama 2002; Hanya et al. 2004). Barbary macaques live

102 in isolated forest patches in Morocco and Algeria $\left(\underline{31-36^{\circ} \mathrm{N}}\right)$. They live from

103 lowland thermophilous scrub through mid-altitude mixed deciduous and evergreen oak

104 forest and high-altitude coniferous forest (Fa 1984b). Among the extant macaques,

105 Barbary macaques represent a relatively ancient branch (Fa 1989). Some data on other

106 temperate species are available, but we have not examined them in detail, as we have

107 done for the Barbary and Japanese macaques because data for those other species are

108 scanty, in particular habitat data.

109 Based on our original data and review of published articles, we examine 1)

110 the difference in tree species diversity and composition between the two habitats; 2) the

111 annual diet of the two species, with special reference to fruit/seed- and leaf-eating; 3)

112 the relationship between fruit/seed availability and fruit/seed-eating in the two species,

113 in order to clarify the preferences for fruit/seeds by these macaques; and 4) leaf

114 chemistry of food and non-food tree leaves, in order to reveal the difference in selection

115 criterion of leaf foods in response to the habitat differences.

\section{Methods}

$118 \quad$ Vegetation

119 Data on the vegetation of macaque habitats were derived from our published (Ménard 
120 and Vallet 1988; Hanya et al. 2003) and unpublished data. Data from six sites in Japan

121 and two sites in Algeria were compared. We sampled trees of $\geq 5 \mathrm{~cm}$ in diameter at

122 breast height (DBH). The number of species and the Shannon-Wiener diversity index

123 (Clutton-Brock 1977) were compared. In the calculation of the diversity index, each

124 species was evaluated either by basal area or coverage. We controlled for the effect of

125 area on species diversity by comparing plot sizes of 0.5 ha, in some cases obtained by

126 extrapolation (Colwell and Coddington 1994), using the software program 'EstimateS'.

128 Diet

129 Annual dietary composition was compared primarily by using observational data of 12

130 months or more, expressing dietary composition according to feeding time. Data were

131 available for three sites (lowland and coniferous forest of Yakushima and deciduous

132 forest of Kinkazan) for Japanese macaques (Hill 1997; Hanya 2004; Tsuji et al. 2006)

133 and two sites for Barbary macaques (deciduous oak forest of Akfadou and

134 coniferous/evergreen broad-leaved forest of Djurdjura, Algeria) (Ménard 1985; Ménard

135 and Vallet 1986). For comparative purposes, data on annual diet of three species of

136 tropical macaques (M. nigra, M. fascicularis and $M$. radiata), studied by scan sampling

137 (Ali 1986; Yeager 1996; O'Brien and Kinnaird 1997), are also shown. Data on monthly

138 changes were not available for the tropical macaques. At Kinkazan, data were obtained

139 over several years and included all 12 calendar months. At other sites, data were taken

140 for at least 12 consecutive months. In the lowland forest of Yakushima, data were taken

141 for 1.5 years, but we used data for only the first 12 consecutive months.

142 At the two North African sites, we used the scan sampling method, recording

143 the activity of the first five animals seen every $10 \mathrm{~min}$. At Yakushima, we used focal 
144 sampling of adults and recorded behavior by instantaneous 1-min sampling (lowland

145 habitat) or continuous sampling (coniferous forest). At Kinkazan, both scan sampling

146 (every ten or five minutes) of all visible individuals and continuous focal-animal

147 sampling of adult females were used. There are methodological differences among the

148 studies, but for rough comparison of major food items, these can be neglected (Fragaszy

149 et al. 1992). In lowland Yakushima, annual dietary composition described by scan

150 sampling (Agetsuma and Nakagawa 1998; data not used because observations for

151 January were lacking) is similar to that obtained by focal animal sampling (Hill 1997;

152 data used in this paper). Dietary data were expressed as the proportion of the food in the

153 annual feeding time. The actual proportion of each food's intake may be different from

154 the value expressed by feeding time. However, this should not matter for comparative

155 purposes, such as the evaluations in this study. Other types of data, e.g. data

156 representing diet by energy intake or data of less than one year, were used ad libitum.

158 Leaf chemistry

159 Data on leaf chemistry for Japanese macaques in Yakushima are taken from Hanya et al.

160 (2007), but the data for Barbary macaques in Moyen Atlas, Morocco, are original. In

161 Yakushima and Moyen Atlas, both food and non-food leaves were sampled. In

162 Yakushima, food leaves were determined from our observational data covering a

163 one-year period in the coniferous and lowland forests (Hanya et al. 2007). For non-food

164 leaves, all of the species which appeared in two vegetation plots but were not eaten by

165 macaques were examined. The vegetation plots were $50 \mathrm{~m} \times 50 \mathrm{~m}$ and $5 \mathrm{~m} \times 1500 \mathrm{~m}$ in

166 lowland and coniferous forests, respectively. Both plots, although having different sizes

167 and shapes, reflect typical macaque habitat characteristics (Hanya et al. 2007). Since 
there was no essential difference in leaf selection between the two habitats (Hanya et al. 2007), data on coniferous and lowland forests were combined. Leaves were sampled in

170 September 2000, 2004 and 2005. In Moyen Atlas, leaves of all species listed in Table

1716.4 of Drucker (1984) (except introduced species), representing food species and major

172 trees in Moyen Atlas, were sampled. Among them, food leaves were determined using

173 the comprehensive food list of Barbary macaques in Appendix II of Fa (1984a). Leaves

174 were sampled in late September and early October 2005. The numbers of food and non-food leaf species sampled were, respectively, 24 and 54 in Yakushima and 13 and 16 in Moyen Atlas. Sampling periods were determined by the following conditions: 1)

177 several months after the leaf flush in spring, 2) before the deciduous species shed leaves

178 in late autumn 3) when at least some leaf eating was observed. Since the sites' sampling

179 periods roughly matched, data were comparable. species was rare ( 2 species for each area, sampled for only one tree). At least 20 leaves were sampled for each species. Collected leaves were kept in paper envelopes and

183 brought to field stations where they were immediately dried at $40^{\circ} \mathrm{C}$ for 24 hours.

184 Pre-dried leaves were kept in plastic bags and brought to the laboratory at the Primate

185 Research Institute, Kyoto University, where they were dried again at $40^{\circ} \mathrm{C}$ for 48 hours

186 by a vacuum incubator. After weighing, leaves were ground, sieved through a $0.5-\mathrm{mm}$

187 mesh, put in plastic tubes, and kept in a desiccator.

All of the chemical analyses were done at the Primate Research Institute,

189 Kyoto University, under the same protocol. Crude protein was determined using the

190 Kjeldahl procedure for total nitrogen and multiplying by 6.25 (Hasegawa 1993). Crude

191 lipid was measured as diethyl-ether extract by the Soxhlet method (Hasegawa 1993). 
192 Crude ash was determined by ashing at $550^{\circ} \mathrm{C}$ (Hasegawa 1993). Neutral detergent fiber

193 (NDF) was estimated following the methods of van Soest et al. (1991). Condensed

194 tannin was extracted with $50 \%$ methanol and determined by the buthanol-HCl method

195 (Porter 1989). Condensed tannin concentration was calibrated from the absorbance at

$196550 \mathrm{~nm}$, using the known concentration of cyanidin chloride. Hydrolysable tannin

197 extracted with $70 \%$ aqueous acetone was determined by the potassium iodine method

198 (Willis and Allen 1998). Hydrolysable tannin concentration was calibrated as a tannic

199 acid equivalent from the absorbance at $550 \mathrm{~nm}$. The available standards of tannins

200 substantially overestimate or underestimate tannin concentration (Rautio et al. 2007),

201 so the reported values of tannin are used only for comparative purposes (food vs.

202 non-food or Yakushima vs. Moyen Atlas) in this study.

203 With respect to leaf chemistry, we conducted two kinds of analysis. First, in

204 order to analyze leaf selection at each study site, we used the generalized linear model

205 (GLM) based on whether macaques ate the species $(0=$ non-food, $1=$ food $)$ as a

206 dependent variable and the above-mentioned six chemical properties as independent

207 variables. This analysis was conducted separately for each site. All possible

208 combinations of independent factors were examined, and the model fitness was assessed

209 by Akaike's Information Criterion, or AIC (Burnham and Anderson 2002). We

210 examined only the model having a $\triangle$ AIC (difference with the smallest AIC) of less than

211 two. In order to assess the relative likelihood of these models, we calculated Akaike

212 weight as: $\exp \left(\_0.5 * \Delta \mathrm{AIC}\right.$ score for that model $) / \operatorname{sum}$ of $\exp (-0.5 * \Delta \mathrm{AIC}$ score $)$ for all

213 of the models (Burnham and Anderson 2002). Second, in order to determine the

214 difference in the chemical properties of food leaves between the two macaque species,

215 we compared the six chemical properties of food leaves between the sites by the t-test. 
216 Since six analyses were run, the alpha level was set to $0.05 / 6=0.0083$, using

217 Bonferroni correction (Curtin and Schulz 1998).

218

219 Results

220 Habitat

221 Habitats of Japanese macaques were richer in tree species, in particular fleshy-fruited species, than those of Barbary macaques, although the same genera or families were often dominant in both regions. When comparing the number of species per 0.5 ha, the Japanese forests had 18-61 tree species, including 7-35 fleshy-fruited species. On the other hand, the North African forests had only four or five tree species (all non-fleshy). As for the diversity index, quantitative comparison is difficult due to the difference in plot size and sampling method (basal area is used in most of the Japanese forests, and coverage is used in the North African forests). However, all of the Barbary macaque habitats had lower diversity indices than the Japanese macaque habitats (Table I). In one study site where the diversity index was calculated from both coverage and basal area,

231 coverage resulted in a higher index than did basal area. If this held true for North

232 African sites, the difference in diversity between Algeria and Japan may have been

233 larger than shown in Table I. Even when a much broader area was covered ( 84 forests over $20 \mathrm{~km} \times 70 \mathrm{~km}$ ), both number of species and diversity were lower in the Barbary macaque habitat (Ajbilou et al. 2006) than in any of the Japanese macaque habitats.

236 Fleshy-fruited species constituted more than half of the tree species in Japanese forests

237 but only a small portion (0-33\%) in North African forests. In both habitats, oaks

238 (Quercus) were dominant in lowlands and conifers (Cedrus and Pinus in North Africa

239 and Abies, Cryptomeria and Tsuga in Japan) were dominant in high-altitude forests. 
241 Diet

242 Among the five populations, the proportion of time spent feeding on leaves was highest

243 for Barbary macaques in the coniferous/evergreen broad-leaved forest of Djurdjura

$244(48 \%)$ and second highest in Japanese macaques in the coniferous forest of Yakushima

245 (41\%) (Fig. 1). The proportion of time spent feeding on seeds was highest for Japanese

246 macaques in the deciduous forest of Kinkazan (44\%), followed by two Barbary

247 macaque populations (26\% and $32 \%$ ) and Japanese macaques in the lowland forest of

248 Yakushima (34\%); however, this value was low in the coniferous forest of Yakushima

249 (4\%). The proportion of fruit-eating time was higher for Japanese macaques (10-24\%)

250 than Barbary macaques (0.8-4.3\%). Lichen constituted a considerable proportion of

251 feeding time of the Barbary macaques in the deciduous oak forest of Akfadou (14\%). It

252 has not been reported that Japanese macaques eat lichens. In the coniferous forest of

253 Yakushima, the macaques also spend considerable time feeding on mushrooms (14\%).

254 Compared with tropical macaques, time spent feeding on fruits was considerably lower

255 (54-67\% for tropical vs. 0.8-25\% for temperate macaques).

256 Barbary macaques eat more herbs than Japanese macaques. Barbary macaques

257 in the coniferous/evergreen broad-leaved forest of Djurdjura spent $54 \%$ of their annual

258 feeding time on herbs, constituting $35 \%$ leaves, $8 \%$ root and $11 \%$ seeds, and those in the

259 deciduous oak forest of Akfadou spent $32 \%$ of feeding time on herbs (19\% leaves, $7 \%$

260 roots and 6\% seeds) (Ménard 2002). Japanese macaques in the coniferous forest of

261 Yakushima spent only $15 \%$ of annual feeding time on herbs (9\% leaves, $3 \%$ roots, $1 \%$

262 seeds) (Hanya 2004), and those at Kinkazan spent $28 \%$ of annual feeding time on herbs

263 (leaves 25\% and fruits 3\%) (Tsuji et al 2006; Tsuji et al. unpublished data). Hill (1997) 
264 does not report the herb feeding time. However, according to Agetsuma and Nakagawa

265 (1998), who reported the food composition of Japanese macaques in the lowland of

266 Yakushima for 11 calendar months, herb feeding time was only $3 \%$ of the annual

267 feeding time.

Seasonal changes in diet were similar in the two species, although the

269 absolute feeding time was considerably different (Fig. 2). In the case of Japanese

270 macaques, leaf eating was dominant in winter (January-March) or spring (April-June),

271 since fruits and seeds were not available and macaques ate mature leaves as fallback

272 foods (Hanya 2004) or because protein-rich young leaves are available. Fruit and seed

273 eating occurred most often in autumn (September-November) and intermediately in

274 summer (July and August, except in the coniferous forest of Yakushima).

275 Mushroom-eating was observed in various months for Japanese macaques, most often

276 in summer. In summary, Japanese macaques ate young leaves in spring, various foods

277 such as fruits, mature leaves, fungi, seeds and animals (mostly insects) in summer, and

278 fleshy fruits and seeds (in particular acorns) in autumn. In winter, after consuming the

279 fruits and seeds produced in the preceding autumn, they ate mature leaves of evergreen

280 trees in evergreen forests or bark and winter buds in deciduous forests. The same pattern

281 has also been reported at other sites, such as the warm-temperate forest of Koshima or

282 the cool-temperate forest of Shiga Heights (Suzuki 1965; Iwamoto 1982). Barbary

283 macaques also ate leaves in spring, various foods such as fruits, seeds, leaves, lichens

284 and roots in summer, acorns and conifer (Abies and Cedrus) seeds in autumn, and leaves

285 and lichens (Akfadou only) in winter. Similar patterns have been reported from Rif or

286 Moyen Atlas (Drucker 1984; Mehlman 1988; Ménard and Qarro 1999). 
prefer seeds but not fruits. It has already been shown that Japanese macaques in the coniferous forest of Yakushima increased their feeding time on fruits and seeds with increasing availability (Hanya 2004). We analyzed the relationship between fruit/seed eating and availability for Barbary macaques in Moyen Atlas using the data by Drucker

292 (1984), expressing monthly dietary composition by energy intake. They ate fleshy fruits

293 of lianas from February to April and acorns from August to November. Monthly feeding

294 time on seeds and seed availability correlated significantly $(r=0.969, P<0.0001)$.

295 However, correlation between the monthly feeding time on fruits and fruit availability

296 was not significant $(r=0.569, P=0.523)$.

298 Leaf chemistry

299 Condensed tannin and lipid content affected leaf selection of Japanese macaques, but no 300 chemical factor significantly affected leaf selection of Barbary macaques (Tables II and III). GLM analysis revealed that all of the models having $\Delta \mathrm{AIC}<2$ included condensed tannin, hydrolysable tannin, and crude lipid (all negative effect), and thus the effects of

303 these three factors were robust. On the other hand, in the analysis of Barbary macaques,

304 a null model having no independent factor had the smallest AIC, and none of the other 305 models having $\Delta$ AIC $<2$ were significant.

307 the food leaves of Barbary macaques included significantly higher condensed tannins,

308 hydrolysable tannin, and crude lipid (condensed tannin: $t=3.92, P=0.004$;

309 hydrolysable tannin: $t=3.13, P=0.0035$; crude lipid: $t=4.17, P=0.0002)$. On the

310 other hand, the content of crude protein, neutral detergent fiber and crude ash did not

311 differ significantly between the two macaques (crude protein: $t=2.12, P=0.041$; 
312 neutral detergent fiber: $t=2.75, P=0.0093$; crude ash: $t=0.838, P=0.41$ ).

313

314 Discussion

315 We established that tree species diversity, in particular fleshy-fruited species, is higher

316 in Japan than in North Africa. Both Japanese and North African forests are dominated

317 by Quercus (lowland) and conifers (high altitude forests), but North African forests

318 consist almost exclusively of those dominant species. This difference significantly

319 affected the feeding ecology of the two macaque species.

320

321 Similarities

322 In response to the pronounced seasonal changes in temperature and fruiting phenology,

323 which is a more-or-less universal pattern among temperate forests (Ting et al. 2008),

324 both Japanese and Barbary macaques showed qualitatively similar patterns of seasonal

325 dietary change. They eat young leaves in spring, various foods including fruits, mature

326 leaves, and fungi in summer, fruits and/or seeds in autumn, and leaves and other

327 vegetative foods such as mature leaves, buds and bark in winter. A similar pattern can

328 also be seen for Taiwanese macaques (Su and Lee 2001). The dietary pattern of rhesus

329 macaques in Pakistan seems a bit different; since they increase fruit eating in the

330 monsoon season (July-September) between dry early summer and dry autumn

331 (Goldstein and Richard 1989). In this area, the greatest fruit diversity and biomass is

332 available for macaques in the monsoon season (Goldstein and Richard 1989).

333 Barbary macaques share many dietary characteristics with Japanese macaques,

334 which have been proposed by Hanya (2004) as adaptive strategies to survive in

335 temperate habitat. Barbary macaques also rely considerably on leaves. It is known that 
336 primates in Asia, in particular cercopithecines, tend to use leaves as fallback foods

337 compared to primates in other regions (Hemingway and Bynum 2005). The dependence

338 on leaves may have been an important prerequisite for macaques to survive in temperate

339 forests. At the same time, they prefer seeds, which contain less fiber and more digestible

340 carbohydrates than leaves (Janson and Chapman 1999), such as those of Quercus,

341 Cedrus and fir (Abies), and they eat them whenever available. Although this tendency

342 was statistically confirmed for only Moyen Atlas, Ménard (2002) mentioned that in

343 North African forests, acorns are available from autumn to winter, which coincides with

344 the acorn-eating period of Barbary macaques. Likewise, fir seeds are a major

345 component of the Barbary macaque diet in the Rif Mountains when they are abundant

346 (Mehlman 1988).

Differences

Japanese and Barbary macaques differ with respect to their degree of reliance on herbs and fleshy fruits, and their leaf selection. These differences seem to be related to the lower tree species diversity in North Africa than in Japan. macaques compensate for low tree species diversity by consuming herbs. In the two

354 North African forests (Djurdjura and Akfadou), the two most dominant species (Quercus and Cedrus) account for more than 95\% of the trees in coverage (Ménard and Vallet 1988). Barbary macaques eat the leaves and seeds of both species, but seeds are available only for a limited period. Leaves of herbs may be more palatable than tree

358 leaves due to their low fiber (Waterman 1984). In addition, excessive consumption of the leaves of one or a few species may overload the detoxifying capacity of animals for 
360 a particular toxin contained in the leaves (Janson and Chapman 1999). Japanese

361 macaques at Kinkazan relied more heavily on herbs than those at Yakushima. The

362 forests of Kinkazan have been degraded by overgrazing of sika deer, and some forests

363 were converted to grasslands (Tsuji and Takatsuki 2004), so Japanese macaques also

364 supplement their diet with herbs when food resources are scarce. Even stronger

365 dependence on herbs has been reported for another temperate primate, the rhesus

366 macaques in northwest Pakistan (Goldstein and Richard 1989). They live in a degraded

367 habitat where vegetation has been damaged by logging, overgrazing by cattle, and

368 natural disturbances. Feeding on herbs constituted $68 \%$ of the total feeding time of this

369 population. Macaques mostly utilize forest habitat (Hanya et al. 2002), but they seem to

370 be able to subsist largely on herbs, especially in poor temperate habitats. Both Barbary and Japanese macaques often consumed considerable amounts of seeds, but most populations consumed fruits when they were available (Fig. 2). Seeds preferred by Barbary macaques came from the dominant plants of the forest (e.g. community. Therefore it was difficult to determine whether Barbary macaques actually preferred fleshy fruits over seeds. On the other hand, Japanese forests harbor many fleshy-fruited tree species. Many of these are common and supply a considerable amount of food for the macaques (Hanya et al. 2003).

380 food leaves by Japanese macaques (Hanya et al. 2007). In North Africa, however, the

381 effect of chemical properties may be masked by the effect of uncertain availability. The

382 more palatable leaves may be simply not available for the Barbary macaques in this 383 low-diversity forest. 
We found that Japanese macaques avoided leaves with high condensed tannin,

385 hydrolysable tannin, and crude lipid content. It is not evident why Japanese macaques

386 avoided leaves with high crude lipid, but they may dislike the non-fat constituents

387 included in crude lipid, such as waxes, cutins and pigments (Bleisch et al. 1998). On the

388 other hand, the food leaves of Barbary macaques contained more tannin (both

389 condensed and hydrolysable) and crude lipid than those eaten by Japanese macaques. In

390 Yakushima, coniferous leaves, such as Abies, Tsuga and Cryptomeria, contain large

391 amounts of condensed tannin (1.9\%, $1.3 \%$ and $0.5 \%$, respectively), and Japanese

392 macaques never eat these leaves. The condensed tannin contents of these leaves were

393 4.1-15.7 times higher than the average for the food leaves (0.12\%). In Moyen Atlas,

394 conifer leaves such as Cedrus and Juniperus also contain much condensed tannin (2.4\%

395 and 3.7\%, respectively), but Barbary macaques eat conifer leaves not only in Moyen

396 Atlas but also in other habitats, such as Rif (Mehlman 1988) and Djurdjura (Ménard and

397 Vallet 1986). In addition, condensed tannin content was higher in Moyen Atlas than in

398 Yakushima not only for dominant species but also on average. The same pattern was

399 found for hydrolysable tannins (Hanya et al., unpublished data). Barbary macaques

400 survive in an environment where tree species diversity is low and leaves contain much

401 tannin. On the other hand, most Japanese macaque habitats are covered with

402 broad-leaved trees, and conifers are dominant only in high mountains (Yamagiwa and

403 Hill 1998). However, broad-leaved trees are available even in coniferous forest (Table I),

404 so Japanese macaques do not need the capacity to tolerate high levels of condensed

405 tannin. It remains an open question whether Barbary and Japanese macaques have

406 developed different detoxifying abilities for tannins. Interestingly, similar situations are

407 reported in two species of closely related rodents (Skopec et al. 2008). However, the 
408 evidence is equivocal, since specialists on tannin-rich oaks are known to have higher

409 detoxifying abilities for tannins than sympatric generalist species, but these two species

410 showed similar responses of body weight and survival in a feeding experiment on oak

411 leaves (Skopec et al. 2008). Experimental studies are necessary for the two macaque

412 species.

413

414 Conclusions and future directions in the study of temperate primates

This study has shown that both Japanese and Barbary macaques adapt to

416 temperate habitats in similar ways. They spend much time eating leaves and other

417 vegetative foods and select seeds and fruits when they are available. Barbary macaques

418 appear to have a high tolerance for secondary compounds in leaves, which may be expected in their environment with lower tree species diversity. Animals can survive during the lean period by consuming leaf and other vegetative foods and by metabolizing the fat deposited from eating fruits and seeds during the food-abundant period. This will lead to decreases in body weight during winter (Wada 1975; Kurita et al. 2002). Such dietary switching is a common response to the deterioration of food resources in many tropical forests as well (van Schaik and Pfannes 2005). It has already been reported that the degree of seasonal dietary variability increases with increasing latitude (Hemingway and Bynum 2005), and our close examination of the two temperate species confirmed this. Temperate primates may show the extreme of this strategy because of the prolonged period of fruit scarcity and the lack of fallback fruits, such as Ficus or Musanga, which are often available to tropical primates even when

430 other fruits are not available (Terborgh 1983; Furuichi et al. 2001). In fact, Japanese and 431 Barbary macaques depend on leaf and other vegetative foods (45\% and 55\% of diet, 
432 respectively, for one population of each), as do the "folivorous" colobines (average for

43324 species: $52 \%$ of diet) (Kirkpatrick 1999). These temperate macaques consume no

434 fruits/seeds and rely exclusively on fallback foods such as fibrous foods and lichen in

435 some months of the year (Fig. 2), a pattern not seen in tropical macaques (Ali 1986;

436 Yeager 1996; O'Brien and Kinnaird 1997). Therefore, leaves and lichen are 'staple', not

437 'filler' fallback foods for temperate macaques (Marshall and Wrangham 2007). Fat

438 deposition is commonly reported for temperate endotherms (Pond 1978), including

439 Japanese macaques (Wada 1975), but data on this are scarce for tropical primates.

440 Interestingly, fat deposition has been reported in orangutans living in a habitat

441 experiencing considerable supra-annual mast fruiting (Knott 1998). Future work on

442 physiological and genetic analyses of fat deposition, digestion and detoxification

443 abilities of temperate macaques would further support our conclusion.

444 In order to generalize these findings, more work is needed on other species. A

445 comparison with Rhinopithecus, another lineage radiated in temperate regions, would be

446 particularly interesting. The dependence on leaves and the preference for fruits are

447 compatible in macaques because they are caeco-colic-fermenters which can digest both

448 leaves and fruits (Lambert 1998), but this may not be so in the case of

449 forestomach-fermenting colobines. Interestingly, Rhinopithecus prefer young leaves but

450 rely heavily on lichens as fallback foods (Grueter et al. 2009), which are also eaten by

451 Barbary macaques. Lichens are composed of largely water-soluble carbohydrates,

452 whose digestibility is higher than NDF (Kirkpatrick et al. 2001), so they might be a

453 better food than mature leaves. A comparison between Macaca and Rhinopithecus

454 would be useful in helping us understand the kinds of adaptations required for primates

455 to survive in temperate forests. 
Acknowledgements

We would like to thank our friends and colleagues who supported our fieldwork in

459 Japan, Morocco and Algeria. The Ministry of Environment and Forestry Agency, Japan,

460 and Haut Commissariat aux Eaux et Forêt et à la Lutte Contre la Désertification,

461 Morocco gave us permission to study in the area. Dr. Y. Tsuji kindly provided his

462 published data. This study was financed by the JSPS Core-to-core Program HOPE,

463 Cooperation Research Program of KUPRI and the MEXT Grant-in-Aid for JSPS

464 Fellows, Grant-in-Aid for Young Scientists (\#20770195 and \#22687002) to GH, the

46521 st Century COE Program (A14) and Global COE Program "Formation of a Strategic

466 Base for Biodiversity and Evolutionary Research: from Genome to Ecosystem.”

467

468

References

Agetsuma N (1995) Dietary selection by Yakushima macaques (Macaca fuscata yakui): the influence of food availability and temperature. Int J Primatol 16: 611 -627.

Agetsuma N, Nakagawa N (1998) Effects of habitat differences on feeding behaviors of Japanese monkeys: Comparison between Yakushima and Kinkazan. Primates 39: $275-289$.

Ajbilou R, Maranon T, Arroyo J (2006) Ecological and biogeographical analyses of Mediterranean forests of northern Morocco. Acta Oecol 29: 104-113.

Ali R (1986) Feeding ecology of the bonnet macaque at the Mundanthurai Sanctuary, Tamil Nadu. J Bombay Nat Hist Soc 83: 98-110.

Bleisch W, Liu Z, Dierenfeld E, Xie J (1998) Selected nutrient analysis of plants in the diet of the Guizhou snub-nosed monkey (Rhinopithecus [Rhinopithecus] brelichi). 
480 In: Jablonski N (ed) The Natural History of the Doucs and Snub-nosed Monkeys.

$481 \quad$ World Scientific Publishing, Singapore, pp 241-254

482 Burnham KP, Anderson DR (2002) Model Selection and Multi-model Inference. 2nd

$483 \quad$ Edition. Springer, New York.

484 Clutton-Brock TH (1977) Primate Ecology: Studies of Feeding and Ranging Behaviour 485 in Lemurs, Monkeys and Apes. Academic Press, Brighton.

486 Colwell RK, Coddington JA (1994) Estimating terrestrial biodiversity through

487 extrapolation. Philos Trans R Soc Lond Ser B-Biol Sci 345: 101—118.

488 Curtin F, Schulz P (1998) Multiple correlations and Bonferroni's correction. Biol

$489 \quad$ Psychiatry $44: 775-777$.

490 Drucker GR (1984) The feeding ecology of Barbary macaque and cedar forest

491 conservation in the Moroccan Moyen Atlas. In: Fa JE (ed) The Barbary Macaque: A 492 case study in Conservation. Plenum Press, New York, pp 135-164

493 Fa JE (1984a) The Barbary Macaque: A Case Study in Conservation. Plenum Press, $494 \quad$ New York.

495 Fa JE (1984b) Habitat distribution and habitat preference in Barbary macaques (Macaca 496 sylvanus). Int J Primatol 5: 273-286.

497 Fa JE (1989) The Genus Macaca: a review of taxonomy and evolution. Mammal Rev $498 \quad 19: 45-81$.

499 Fleagle JG (1999) Primate Adaptation and Evolution. Second Edition. Academic Press, $500 \quad$ London.

501 Fragaszy DM, Boinski S, Whipple J (1992) Behavioral sampling in the field:

502 Comparison of individual and group sampling methods. Am J Primatol 26:

$503 \quad 259-275$. 
504 Furuichi T, Hashimoto C, Tashiro Y (2001) Fruit availability and habitat use by

505 chimpanzees in the Kalinzu Forest, Uganda: Examination of fallback foods. Int J

$506 \quad$ Primatol 22: 929-945.

507 Goldstein SJ, Richard AF (1989) Ecology of rhesus macaques (Macaca mulatta) in

$508 \quad$ northwest Pakistan. Int J Primatol 10: 531—567.

509 Grueter CC, Li DY, Ren BP, Wei FW, Xiang ZF, van Schaik CP (2009) Fallback foods

510 of temperate-living primates: a case study on snub-nosed monkeys. Am J Phys

$511 \quad$ Anthropol 140: 700-715.

512 Hanya G (2004) Diet of a Japanese macaque troop in the coniferous forest of

$513 \quad$ Yakushima. Int J Primatol 25: 55-71.

514 Hanya G, Kiyono M, Takafumi H, Tsujino R, Agetsuma N (2007) Mature leaf selection

515 of Japanese macaques: effects of availability and chemical content. J Zool 273:

$516 \quad 140-147$

517 Hanya G, Noma N, Agetsuma N (2003) Altitudinal and seasonal variations in the diet of

$518 \quad$ Japanese macaques in Yakushima. Primates 44: 51-59.

519 Hanya G, Yamada H, Arakane T (2002) Expeditionary ranging by a Japanese macaque

$520 \quad$ troop in Hieizan. Anthropol Sci 110: 415-420.

521 Hanya G, Yoshihiro S, Zamma K, Matsubara H, Ohtake M, Kubo R, Noma N, Agetsuma

522 N, Takahata Y (2004) Environmental determinants of the altitudinal variations in

523 relative group densities of Japanese macaques on Yakushima. Ecol Res 19:

$524 \quad 485-493$.

525 Hasegawa K (1993) Nutritional Analysis (in Japanese). Baifukan, Tokyo.

526 Hemingway C, Bynum N (2005) The influence of seasonality on primate diet and

527 ranging. In: Brockman DK, van Schaik CP (eds) Seasonality in Primates: Studies of 
528 Living and Extinct Human and Non-Human Primates. Cambridge University Press,

$529 \quad$ Cambridge, pp 57-104

530 Herrera CM (1984) A study of avian frugivores, bird-dispersed plants, and their

$531 \quad$ interaction in Mediterranean scrublands. Ecol Monogr 54: 1—23.

532 Hill DA (1997) Seasonal variation in the feeding behavior and diet of Japanese

533 macaques (Macaca fuscata yakui) in lowland forest of Yakushima. Am J Primatol

$534 \quad 43: 305-322$.

535 Iwamoto T (1982) Food and nutritional condition of free ranging Japanese monkeys on

$536 \quad$ Koshima Islet during winter Primates 23: 153-170.

537 Izumiyama S (2002) Above the forest limit (in Japanese). In: Oi T, Masui K (eds)

538 Natural History of Japanese Macaque: Their Ecological Diversity and Conservation.

539 Tokai University Press, Tokyo, pp 67-77

540 Janson C, Chapman C (1999) Resources and primate community structure. In: Fleagle J,

541 Janson C, Reed K (eds) Primate Communities. Cambridge Univ Press, Cambridge,

$542 \quad$ pp $237-267$

543 Kirkpatrick RC (1999) Colobine diet and social organization. In: Dolhinow P, Fuentes A

544 (eds) The Nonhuman Primates. Mayfield Publishing Company, Mountain View, pp

$545 \quad 93-105$

546 Kirkpatrick RC, Zou RJ, Dierenfeld ES, Zhou HW (2001) Digestion of selected foods

547 by Yunnan snub-nosed monkey Rhinopithecus bieti (Colobinae). Am J Phys

$548 \quad$ Anthropol 114: 156-162.

549 Knott CD (1998) Changes in orangutan caloric intake, energy balance, and ketones in

$550 \quad$ response to fluctuating fruit availability. Int J Primatol 19: 1061-1079.

551 Komiyama A, Kato S, Teranishi M (2001) Differential overstory leaf flushing 
contributes to the formation of a patchy understory. Journal of Forest Research 6:

553 $163-171$.

554 Kurita H, Shiniomura T, Fujita T (2002) Temporal variation in Japanese macaque bodily mass. International Journal of Primatology 23: 411-428.

Lambert JE (1998) Primate digestion: Interactions among anatomy, physiology, and feeding ecology. Evol Anthropol 7: 8-20.

Ménard N (1985) Le régime alimentaire de Macaca sylvanus dans différents habitats $351-466$.

Ménard N (2002) Ecological plasticity of Barbary macaques (Macaca sylvanus). Evol Anthropol 11: 95-100.

Ménard N, Qarro M (1999) Bark stripping and water availability: A comparative study between Moroccan and Algerian Barbary Macaques (Macaca sylvanus). Revue d'Ecologie (La Terre Et La Vie) 54: 123-132.

Ménard N, Vallet D (1986) Le régime alimentaire de Macaca sylvanus dans différents habitats d'Algérie: II. Régime en forêt sempervirente et sur les sommets roucheux.

Ménard N, Vallet D (1988) Disponibilités et utilisation des ressources par le magot Et La Vie) 43: 201-250.

Marshall AJ, Wrangham RW (2007) Evolutionary consequences of fallback foods. Int J Primatol 28: $1218-1235$.

574 Mehlman PT (1988) Food resources of the wild barbary macaque (Macaca sylvanus) in high altitude fir forest, Ghomaran Rif, Morocco. Journal of Zoology 214: 469—490. 
576

577

578

579

580

581

582

583

584

585

586

587

588

589

590

591

592

593

594

595

596

597

598

599

Muroyama Y, Kanamori H, Kitahara E (2006) Seasonal variation and sex differences in the nutritional status in two local populations of wild Japanese macaques. Primates 47: $355-364$.

O'Brien TG, Kinnaird MF (1997) Behavior, diet, and movements of the Sulawesi crested black macaque (Macaca nigra). Int J Primatol 18: 321-351.

Pond CM (1978) Morphological aspects and ecological and mechanical consequences of fat deposition in wild vertebrates. Annual Review of Ecology and Systematics 9: $519-570$.

Porter LJ (1989) Tannins. In: Dey PM, Harborne JB (eds) Methods in Plant Biochemistry, vol1 Plant Phenolics. Academic Press, London, pp 389—419

Rautio P, Bergvall UA, Karonen M, Salminen JP (2007) Bitter problems in ecological feeding experiments: Commercial tannin preparations and common methods for tannin quantifications. Biochem Syst Ecol 35: 257-262.

Sakai S (2002) General flowering in lowland mixed dipterocarp forests of South-east Asia. Biol J Linnean Soc 75: 233-247.

Skopec MM, Haley S, Torregrossa AM, Dearing MD (2008) An oak (Quercus agrifolia) specialist (Neotoma macrotis) and a sympatric generalist (Neotoma lepida) show similar intakes and digestibilities of oak. Physiol Biochem Zool 81: 426-433.

Su HH, Lee LL (2001) Food habits of Formosan rock macaques (Macaca cyclopis) in Jentse, northeastern Taiwan, assessed by fecal analysis and behavioral observation. Int J Primatol 22: 359—377.

Suzuki A (1965) An ecological study of wild Japanese monkeys in snowy areas: focused on their food habits. Primates 6: $31-72$

Terborgh J (1983) Five New World Primates. Princeton University Press, Princeton. 
600 Ting S, Hartley S, Burns KC (2008) Global patterns in fruiting seasons. Glob Ecol $601 \quad$ Biogeogr 17: 648-657.

602 Tsuji Y, Fujita S, Sugiura H, Saito C, Takatsuki S (2006) Long-term variation in fruiting 603 and the food habits of wild Japanese macaques on Kinkazan Island, northern Japan. $604 \quad$ Am J Primatol 68: 1068-1080.

605 Tsuji Y, Takatsuki S (2004) Food habits and home range use of Japanese macaques on 606 an island inhabited by deer. Ecol Res 19: $381-388$.

607 van Schaik CP, Pfannes K (2005) Tropical climates and phenology: a primate

608 perspective. In: Brockman DK, van Schaik CP (eds) Seasonality in Primates:

609 Studies of Living and Extinct Human and Non-Human Primates. Cambridge

$610 \quad$ University Press, Cambridge, pp 23-54

611 van Schaik CP, Terborgh JW, Wright SJ (1993) The phenology of tropical forests:

612 adaptive significance and consequences for primary consumers. Annu Rev Ecol $613 \quad$ System 24: $353-377$.

614 van Soest PJ, Robertson JB, Lewis BA (1991) Methods for dietary fiber, neutral 615 detergent fiber, and nonstarch polysaccharides in relation to animal nutrition. $\mathrm{J}$ $616 \quad$ Dairy Sci 74: 3583 -3597.

617 Wada K (1975) Ecology of wintering among Japanese monkeys in Shiga Heights and its 618 adaptive significance. Physiol Ecol Jpn 16: 9-14.

619 Waterman P (1984) Food acquisition and processing as a function of plant chemistry. In:

620 Chivers DJ, Wood BA, Bilsborough A (eds) Food Acquisition and Processing in $621 \quad$ Primates. Plenum Press, New York, pp 177-211

622 Willis RB, Allen PR (1998) Improved method for measuring hydrolyzable tannins using 623 potassium iodide. Analyst 123: 435-439. 
624 Willson MF, Irvine AK, Walsh NG (1989) Vertebrate dispersal syndromes in some

625 Australian and New Zealand plant communities, with geographic comparisons.

626 Biotropica 21: 133-147.

627 Yamagiwa J, Hill D (1998) Intraspecific variation in the social organization of Japanese

628 macaques: Past and present scope of field studies in natural habitats. Primates 39:

$629 \quad 257-273$

630 Yeager CP (1996) Feeding ecology of the long-tailed macaque (Macaca fascicularis) in 631 Kalimantan Tengah, Indonesia. Int J Primatol 17: 51—62.

632 
Hanya et al.

Diet of temperate macaques

Table I. Number of tree species and diversity in Japanese and north African forests

\begin{tabular}{|c|c|c|c|c|c|c|c|c|c|c|c|}
\hline $\begin{array}{l}\text { Study } \\
\text { site }\end{array}$ & $\begin{array}{l}\text { Cou } \\
\text { ntry* }\end{array}$ & Vegetation & $\begin{array}{l}\text { Area } \\
\text { (ha) }\end{array}$ & $\begin{array}{l}\text { \#Tree } \\
\text { Specie } \\
\text { s }\end{array}$ & $\begin{array}{l}\text { \#Fleshy- } \\
\text { fruited } \\
\text { tree } \\
\text { species }\end{array}$ & $\begin{array}{l}\text { \#Tree } \\
\text { Specie } \\
\mathrm{s} / 0.5 \\
\text { ha }^{* *}\end{array}$ & $\begin{array}{l}\text { \#Fleshy- } \\
\text { fruited } \\
\text { tree } \\
\text { species/ } \\
\text { 0.5ha** }\end{array}$ & $\begin{array}{r}\mathrm{H}(\mathrm{BA} \\
\text { based) }\end{array}$ & $\begin{array}{c}\mathrm{H} \\
\text { (cover } \\
\text { based) }\end{array}$ & $\begin{array}{c}\text { Dominant species } \\
\text { (Top3) }\end{array}$ & Source \\
\hline $\begin{array}{l}\text { Yakushi } \\
\text { ma, } 100 \\
\text { m }\end{array}$ & $J$ & $\begin{array}{c}\text { Evergreen } \\
\text { broad-leaved } \\
\text { forest }\end{array}$ & 0.5 & 52 & 31 & 52 & 31 & 3.17 & - & $\begin{array}{c}\text { Ardisia sieboldii } \\
\text { (Myrsinaceae), Lithocarpus } \\
\text { edulis (Fagaceae), Litsea } \\
\text { acuminata (Lauraceae) }\end{array}$ & $\begin{array}{c}\text { Takafumi } \\
\text {, } \\
\text { Agetsum } \\
\text { a, } \\
\text { Tsujino, } \\
\text { unpublis }\end{array}$ \\
\hline $\begin{array}{l}\text { Yakushi } \\
\text { ma, } 600 \\
\text { m }\end{array}$ & $\mathrm{J}$ & $\begin{array}{c}\text { Evergreen } \\
\text { broad-leaved } \\
\text { forest }\end{array}$ & 0.25 & 18 & 10 & $\underline{18}$ & $\underline{10}$ & 2.04 & - & $\begin{array}{l}\text { Distylium racemosum } \\
\text { (Hamamelidaceae), } \\
\text { Quercus salicina } \\
\text { (Fagaceae), Neolitsea } \\
\text { aciculata (Lauraceae) }\end{array}$ & $\begin{array}{c}\text { Hanya et } \\
\text { al. } \\
\text { (2003) }\end{array}$ \\
\hline $\begin{array}{l}\text { Yakushi } \\
\text { ma, } \\
1050 \mathrm{~m}\end{array}$ & $\mathrm{~J}$ & $\begin{array}{l}\text { Coniferous/e } \\
\text { vergreen } \\
\text { broad-leaved } \\
\text { forest }\end{array}$ & 0.5 & 21 & 10 & 21 & 10 & 2.10 & 2.57 & $\begin{array}{c}\text { Abies firma (Pinaceae), } \\
\text { Cryptomeria japonica } \\
\text { (Taxodiaceae), Tsuga } \\
\text { sieboldii (Pinaceae) }\end{array}$ & $\begin{array}{l}\text { Hanya, } \\
\text { unpublis } \\
\text { hed }\end{array}$ \\
\hline $\begin{array}{c}\text { Koshim } \\
\text { a }\end{array}$ & $\mathrm{J}$ & $\begin{array}{c}\text { Evergreen } \\
\text { broad-leaved } \\
\text { forest }\end{array}$ & 0.5 & 55 & 35 & 55 & 35 & 2.45 & - & $\begin{array}{c}\text { Machilus thunbergii } \\
\text { (Lauraceae), Podocarpus } \\
\text { macrophyllus } \\
\text { (Podocarpaceae), Prunus } \\
\text { jamasakura (Rosaceae) }\end{array}$ & $\begin{array}{l}\text { Go, } \\
\text { unpublis } \\
\text { hed }\end{array}$ \\
\hline $\begin{array}{l}\text { Shiga } \\
\text { Heights }\end{array}$ & $\mathrm{J}$ & $\begin{array}{l}\text { Deciduous } \\
\text { broad-leaved } \\
\text { forest }\end{array}$ & 0.22 & 48 & 10 & $\underline{61}$ & $\underline{13}$ & 2.97 & - & $\begin{array}{c}\text { Betula ermanii } \\
\text { (Betulaceae), Quercus } \\
\text { crispula (Fagaceae), Fagus } \\
\text { crenata (Fagaceae), }\end{array}$ & $\begin{array}{l}\text { Wada, } \\
\text { unpulish } \\
\text { ed }\end{array}$ \\
\hline Muroo & $\mathrm{J}$ & $\begin{array}{c}\text { Deciduous } \\
\text { broad-leaved } \\
\text { forest }\end{array}$ & 0.04 & 14 & 5 & $\underline{25}$ & $\underline{7}$ & 2.25 & - & $\begin{array}{c}\text { Quercus serrata } \\
\text { (Fagaceae), Quercus } \\
\text { glauca (Fagaceae), } \\
\text { Acanthopanax } \\
\text { sciadophylloides } \\
\text { (Araliaceae) }\end{array}$ & $\begin{array}{c}\text { Yamada, } \\
\text { unpublis } \\
\text { hed }\end{array}$ \\
\hline Akfadou & A & $\begin{array}{l}\text { Deciduous } \\
\text { oak forest }\end{array}$ & 0.5 & 4 & 0 & 4 & 0 & - & 0.77 & $\begin{array}{c}\text { Quercus afares } \\
\text { (Fagaceae), Quercus } \\
\text { faginea (Fagaceae), } \\
\text { Quercus suber (Fagaceae) }\end{array}$ & $\begin{array}{l}\text { Ménard } \\
\text { and } \\
\text { Vallet } \\
\text { (1988) }\end{array}$ \\
\hline $\begin{array}{c}\text { Djurdjur } \\
\text { a }\end{array}$ & A & $\begin{array}{l}\text { Coniferous/e } \\
\text { vergreen } \\
\text { broad-leaved } \\
\text { forest }\end{array}$ & 0.5 & 5 & 0 & 5 & 0 & - & 0.73 & $\begin{array}{c}\text { Cedrus atlantica } \\
\text { (Pinaceae), Quercus ilex } \\
\text { (Fagaceae), Pinus } \\
\text { clusiana (Pinaceae) }\end{array}$ & $\begin{array}{l}\text { Ménard } \\
\text { and } \\
\text { Vallet } \\
(1988)\end{array}$ \\
\hline $\begin{array}{l}\text { Northen } \\
\text { Morocc } \\
\text { o (Rif) }\end{array}$ & $\mathrm{M}$ & $\begin{array}{l}\text { Mixed oak } \\
\text { evergreen } \\
\text { and } \\
\text { semidiciduou } \\
\text { s forests }\end{array}$ & $N A^{* * *}$ & 15 & 5 & - & - & 1.85 & - & $\begin{array}{c}\text { Pinus pinaster (Pinaceae), } \\
\text { Quercus canariensis } \\
\text { (Fagaceae), Quercus } \\
\text { coccifera (Fagaceae) }\end{array}$ & $\begin{array}{l}\text { Ajbilou } \\
\text { et al. } \\
(2006)\end{array}$ \\
\hline
\end{tabular}

$\mathrm{H}$ : Shannon-Wiener's diversity index, calculated by the proportion of of each species either as basal area (BA) or coverage. *: J: Japan, A: Algeria, M: Morocco

${ }^{* *}$ : Underlined are estimated values by the method of Colwell and Coddington (1994)

$633{ }^{* * *}$ : Vegetation data of 84 forests of northern Morocco (scattered over an area of $20 \mathrm{~km} * 70 \mathrm{~km}$ ), sapmled by 'nearest neighbr 
Hanya et al.

Diet of temperate macaques

634

Table II. Summary of the generalized linear models on the effect of chemical properties on leaf food selection

a) Japanese macaques in Yakushima

\begin{tabular}{cccc}
\hline Adopted factors & AIC & $\triangle$ AIC & Akaike weight \\
\hline Protein+, Lipid-, Condensed-, Hydrolysable- & 75.4 & 0.0 & $21 \%$ \\
Ash+, Lipid-, Condensed-, Hydrolysable- & 76.9 & 1.6 & $9 \%$ \\
Lipid-, Condensed-, Hydrolysable- & 77.0 & 1.7 & $9 \%$ \\
Protein+, Lipid-, Condensed-, Hydrolysable- & 77.1 & 1.7 & $9 \%$ \\
Protein+, NDF+, Lipid-, Condensed-, Hydrolysable & 77.4 & 2.0 & $8 \%$ \\
\hline
\end{tabular}

b) Barbary macaques in Moyen Atlas

\begin{tabular}{cccc}
\hline Adopted factors & AIC & $\Delta$ AIC & Akaike weight \\
\hline (Null model) & 43.1 & 0.0 & $8 \%$ \\
Condensed+ & 44.2 & 1.2 & $5 \%$ \\
Hydrolysable- & 44.3 & 1.2 & $4 \%$ \\
Protein- & 44.4 & 1.4 & $4 \%$ \\
Ash+ & 44.6 & 1.5 & $4 \%$ \\
Ash+, Condensed+ & 44.7 & 1.7 & $4 \%$ \\
Lipid- & 45.0 & 1.9 & $3 \%$ \\
NDF- & 45.0 & 2.0 & $3 \%$ \\
\hline
\end{tabular}

Protein: crude protein; NDF: neutral detergent fiber; Ash: crude ash; Lipid: crude lipid; condensed: condensed tannin; Hydrolysable: hydrolysable tannin $\triangle \mathrm{AIC}$ : Difference with the smallest AIC

Akaike weight: $\exp \left(-0.5^{\star} \triangle \mathrm{AIC}\right) / \Sigma \exp \left(0.5^{\star} \triangle \mathrm{AIC}\right)$ (Burnham and Anderson, 2002)

+ denotes positive effect (more likely to select as a food) and - denotes negative effect on food selection.

635 Bold indicates that the model is significant (compared with the null model).

636

Table III. Best-fit generalized linear model on the effect of chemical properties on leaf food selection

a) Japanese macaques in Yakushima

\begin{tabular}{cccc}
\hline Adopted factors & Coefficient & SE & $\mathrm{p}$ \\
\hline Crude protein & 19.4 & 10.5 & 0.064 \\
Crude lipid & -37.8 & 14.2 & 0.01 \\
Condensed tannin & -387 & 139 & 0.0053 \\
Hydrolysable tannin & -24.5 & 12.4 & 0.048 \\
\hline
\end{tabular}

In this best-fit model, $\mathrm{df}=72, \mathrm{AIC}=75.4, \mathrm{p}<0.0001$ in the likelihood ratio test using $\mathrm{X}^{2}$ distribution

Coefficient: coefficient by maximum likelihood estimation; SE: standard error of the coefficient, $\mathrm{p}$ : the probability that the coefficient is not different from zero by Wald test.

b) Barbary macaques in Moyen Atlas

637 Null model had the smallest AIC: $\mathrm{AIC}=43.1$ 
638 Legends for figures

639 Fig. 1. Comparisons of annual diet of temperate and tropical macaques. Percentage to

640 total annual feeding time of each food category is shown. Data from (Ménard

641 1985; Ali 1986; Ménard and Vallet 1986; Yeager 1996; Hill 1997; O'Brien and

$642 \quad$ Kinnaird 1997; Hanya 2004; Tsuji et al. 2006).

643 Fig. 2. Seasonal variations in the diet of Japanese and Barbary macaques. Percentage to

644 total monthly feeding time of each food category is shown. Data from (Ménard

645 1985; Ménard and Vallet 1986; Hill 1997; Hanya 2004; Tsuji et al. 2006).

646 Fig. 3. Leaf chemistry of food and non-food leaves of Yakushima (Japanese macaques)

647 and Moyen Atlas (Barbary macaques). Y-axis is the proportion of dry matter.

648 Average+SD is shown. Note that the scale is different among graphs. 
Hanya et al.

Diet of temperate macaques
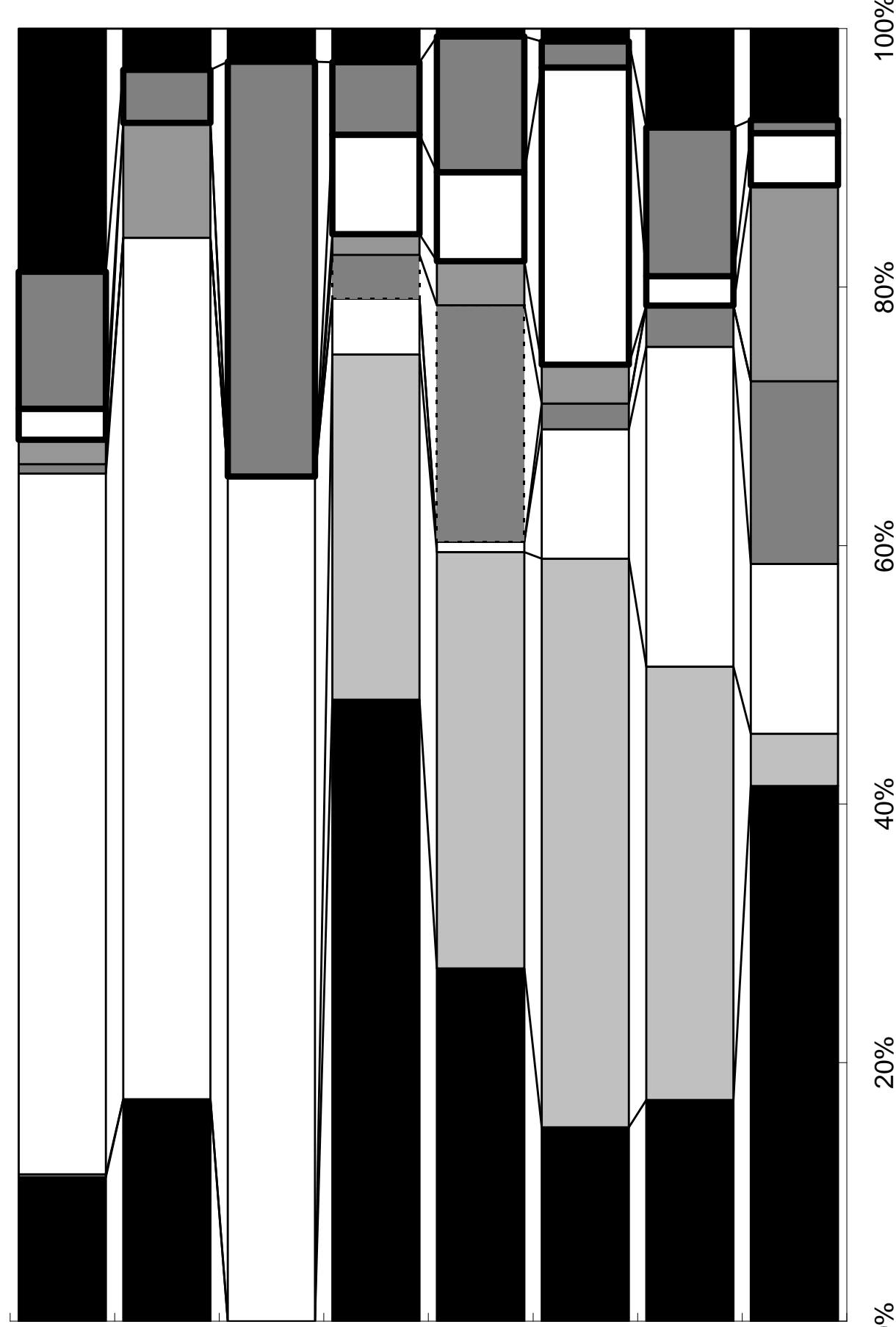

ㅇํㅇㅁ

둔

造

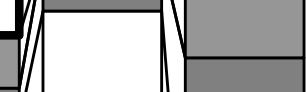

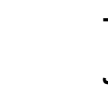

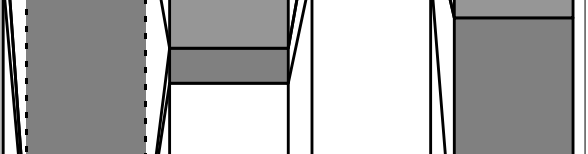

ஃ

ஓ̊

뭉

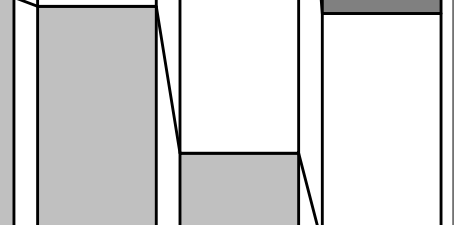

음

믐

ஓ̊ำ

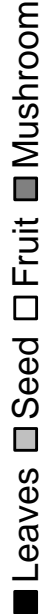

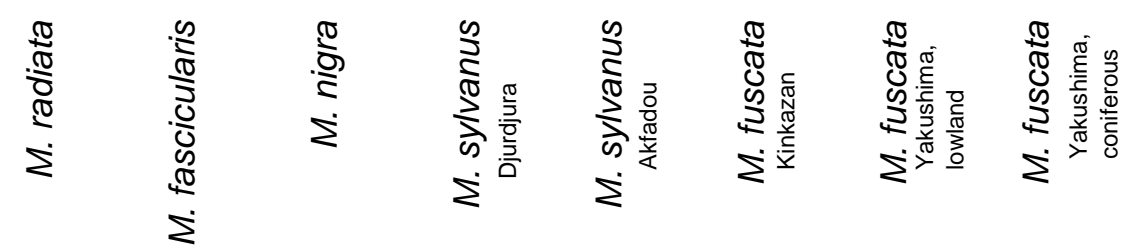

ᄋ̊ํำ

Fig. 1 
M. sylvanus (Djudjura)

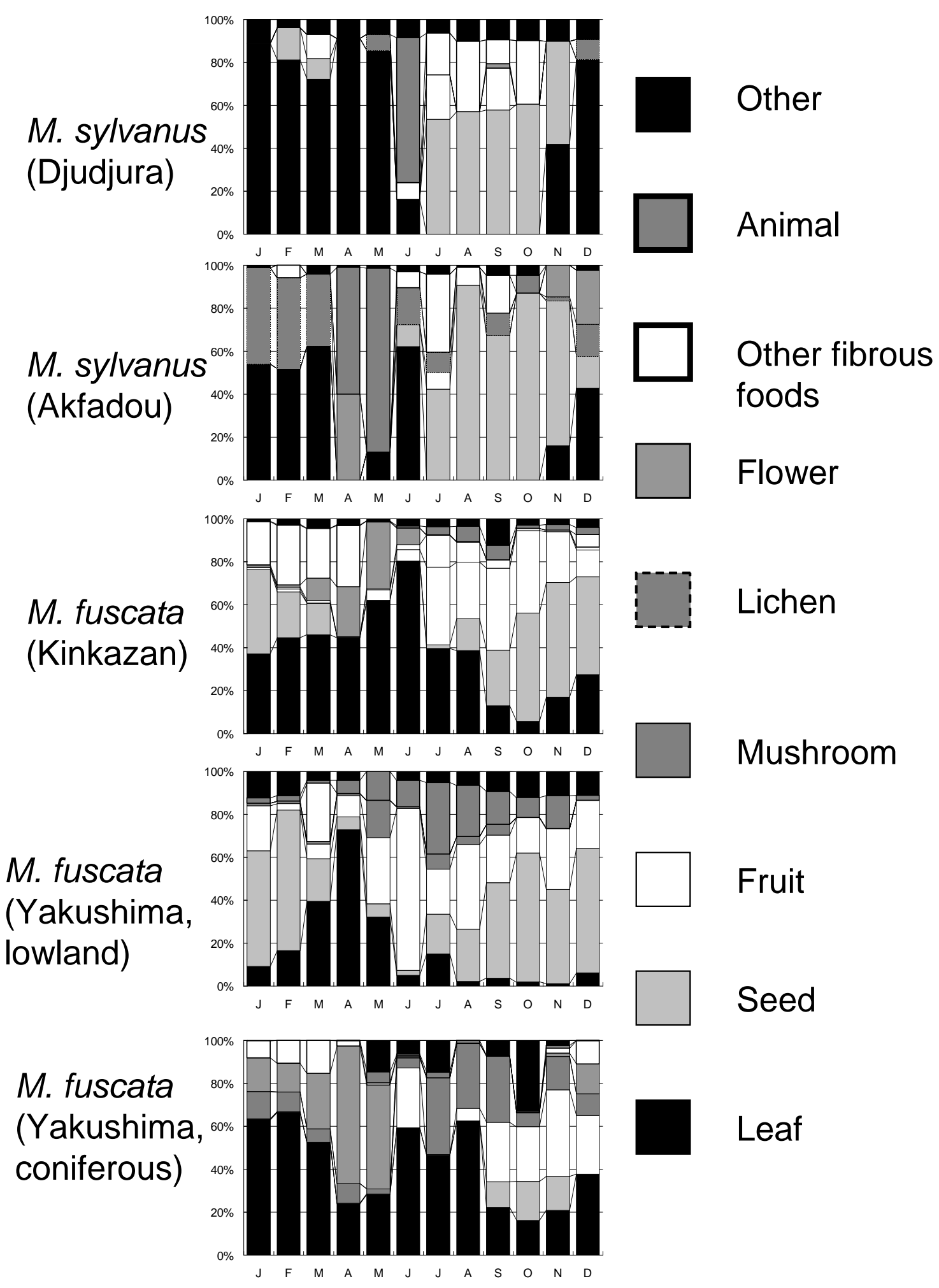

Fig. 2 
Hanya et al.

Diet of temperate macaques

(a) Crude protein

0.16

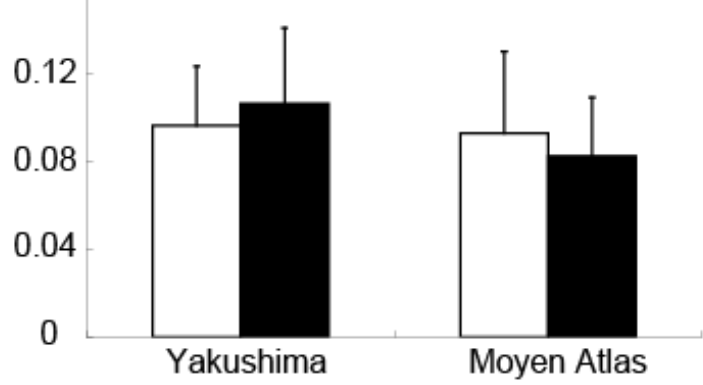

(c) Crude ash

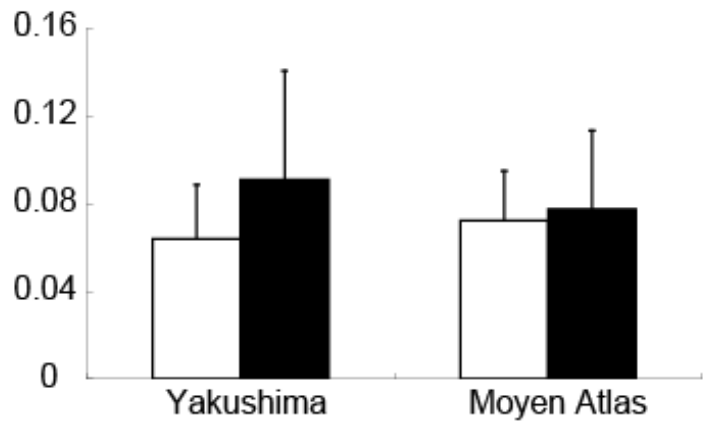

(e) Condensed tannin

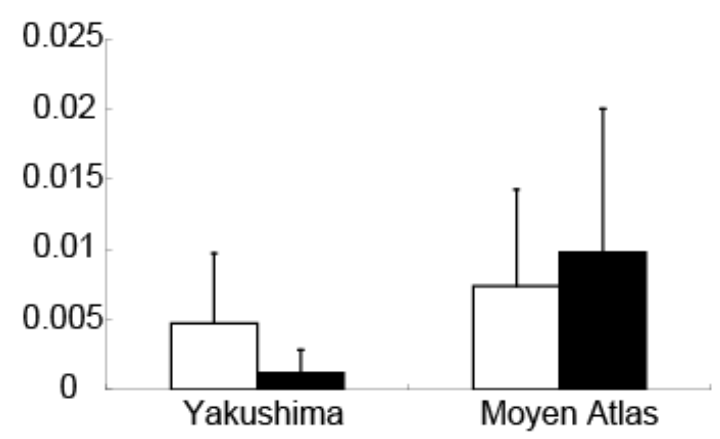

653

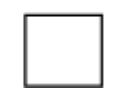

Non-food (b) Neutral detergent fiber

0.6

0.4

0.2

0

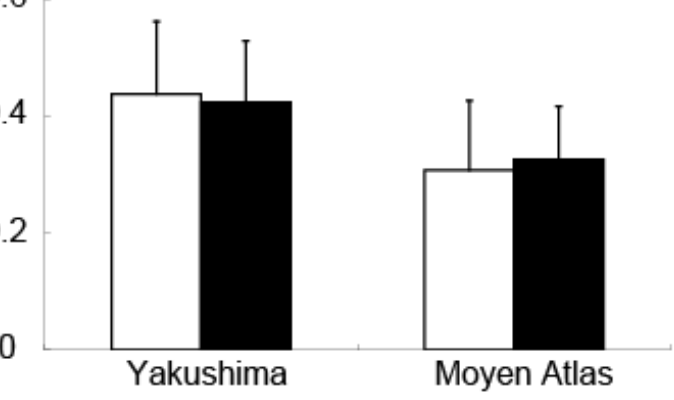

(d) Crude lipid

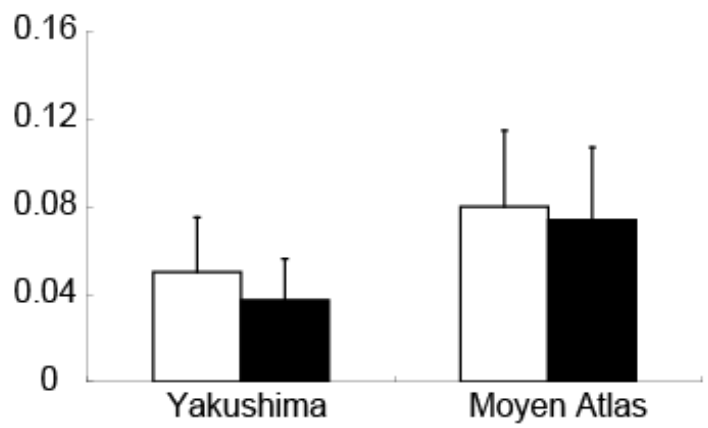

(f) Hydrolysable tannin

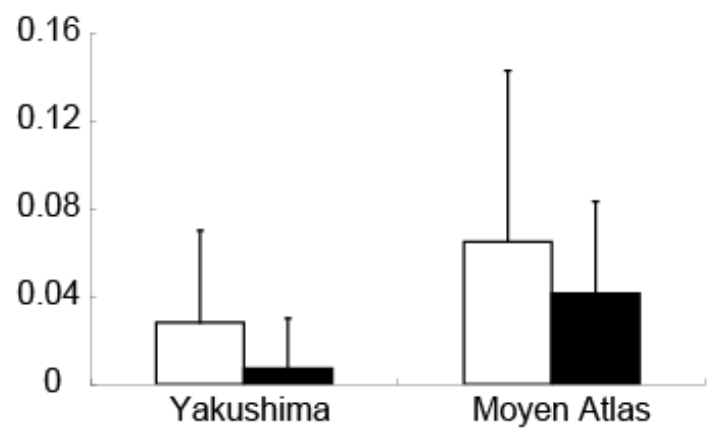

Food

654 Fig. 3 